\title{
Ventilation Systems and COVID-19 Spread: Evidence from a Systematic Review Study
}

\begin{abstract}
Abdolmajid Fadaei ${ }^{1 *}$
${ }^{1}$ Shahrekord University of Medical Sciences, IRAN

*Corresponding Author: ali2fadae@yahoo.com

Citation: Fadaei, A. (2021). Ventilation Systems and COVID-19 Spread: Evidence from a Systematic Review Study. European Journal of Sustainable Development Research, 5(2), em0158. https://doi.org/10.21601/ejosdr/10845

ARTICLE INFO

Received: 8 Jan. 2021

Accepted: 2 Mar. 2021

ABSTRACT

The main transmission mechanism of COVID-19 is through close contact, aerosols, droplets, and fomites transmission of the disease in closed spaces. In this study, the importance of ventilation in preventing the expansion of COVID-19 is reviewed. In total, 20 articles are reviewed. The obtained results show that ventilation has a crucial role in preventing COVID-19 expansion in indoor air environments. However, it should be used properly; otherwise, it will cause further expansion of the disease, as suggested for SARS. Appropriate ventilation can effectively prevent the expansion of COVID-19, and it will be more effective if be combined with particle filtration and air disinfection. The benefit of ventilation in highly polluted outdoor air conditions is an important field to be investigated in future studies. Finally, the results show that the six basic COVID-19 control strategies include: hand hygiene, social distancing, screening and case finding, isolation and separating, decontamination and disinfection, and effective ventilation. We hope that the results of the present study help researchers and health decision-makers in designing programs further perceive the importance of factors related to indoor conditions to control COVID-19 expansion.
\end{abstract}

Keywords: SARS-Cov-2, COVID-19, ventilation, HVAC system

\section{INTRODUCTION}

Pathogens and other respiratory viruses like e.g., coronaviruses, influenza, respiratory syncytial virus, and tuberculosis transmit through the air (Kramer et al., 2006; Sjödin et al., 2020; Tang, 2009). SARS-CoV-2 is a common disease between humans and animals that has turned into a pandemic (Sjödin et al., 2020). According to the literature, close contact is the main transmission route of COVID-19 (mainly respiratory droplets of $>5-10$ ) (Anfinrud et al., 2020). However, still there are controversies concerning the role of droplet nuclei ("aerosolized particles of $<5 \mu \mathrm{m}$ in diameter") when the distance is long (Anfinrud et al., 2020; Bourouiba, 2020). The importance of this transmission method is higher in closed environments in which the majority of individuals spend most of their time (90\%). Several studies mentioned the crucial importance of ventilation in preventing diseases that can be transmitted through the air (Qian and Zheng, 2018). Ventilation is also important for health care settings, where droplets contain pathogens (Jayaweera et al., 2020). There are several studies on ventilation and prevention of COVID-19 infection, including heating, ventilation, and air conditioning (HVAC) systems and bad use of ventilation systems (Correia et al., 2020b; Lu et al., 2020; Mousavi et al., 2020; Somsen et al., 2020a).

Using Wells-Riley equation, the importance of ventilation can be expressed as follows:

$$
P=\frac{C}{S}=1-\exp \left(-\frac{I q p t}{Q}\right)
$$

where P: The cross infection risk, C: number of cases to get infection, S: number of subjects that are likely to become sick, I: number of cases that cause infection (infectors), p: pulmonary ventilation rate of each susceptible subject $\left(\mathrm{m}^{3} / \mathrm{h}\right)$, $Q$ : hourly rate of room ventilation $(\mathrm{m} 3 / \mathrm{h})$, q: rate of average quantum generation produced by one infector (quanta/h) in which a quantum of infection refers to the dose that will on average infect $63 \%$ of the exposed, and $t$ : exposure duration (h). However, the risk of infection and optimal ventilation rate cannot be accurately predicted unless the relationship between exposure to infectious viral aerosols and risk of infection (i.e., viral particles per infectious quantum) for the intended disease is known (Zhu et al., 2020). For example, the prevalence of COVID-19 in a restaurant without windows is reported to be related to the improper use of air conditioning (Lu et al., 2020). Additionally, COVID-19 can be transferred through air in other environments. 
Therefore, in the current review study, we have summarized the findings of articles that investigated the association between climate factors (i.e., temperature, relative humidity $(\mathrm{RH})$, ventilation rate, air filter, and differential pressure) and ventilation in order to describe the role of airconditioning systems in preventing the expansion of COVID19. According to what was mentioned above, evaluating the influence of air-conditioning is important to make appropriate decisions. Hence, the current rapid review study aimed to examine the influence of air-conditioning systems in preventing COVID-19 in indoor environments.

\section{Methods}

In the present study, a multidisciplinary reviewing framework was used to search the quantitative and qualitative articles on indoor ventilation factors. To achieve this goal, we systematically searched PubMed [Medline], JSTOR, Science Direct, Scopus bibliographic, and Google Scholar databases, as well as the Texas A\&M University Library databases using various combinations of the following 32 keywords: "airconditioning” OR "HVAC", "ventilation settings, AND COVID19," "mechanical ventilation system AND indoor pollution," "indoor air quality AND COVID-19," "airflow AND patient," "mechanical ventilation AND infection," and "physical environment AND transmission of COVID-19". Articles on hospital facilities and factors related to the HVAC systems were reviewed. Moreover, references of the identified articles were also reviewed to increase the comprehensiveness of the search. After all titles/abstracts were independently reviewed to determine the potentially related articles, an author selected studies to be fully reviewed.

The identified articles were found eligible after evaluating against inclusion criteria, objectives, and recommended indicators. The inclusion criteria were: having access to the original article, being published in English language, and investigating the correlation between HVAC systems and COVID-19 spread. The exclusion criteria were: lack of access to the full-text article, review studies, book reviews, guidelines, protocols, book chapters, letters-to-editors, articles submitted to conferences, theses, white papers, etc. Information on the authors' name, implementation region, objectives, study design, main variables parameters (e.g., ambient wind, air recirculation, ventilation rate, aerosol, $\mathrm{RH}$, and temperature), and outcomes were collected. The aforementioned criteria were chosen because the final size of exhalation droplets is dependent on several factors, such as the initial size, RH, temperature, ventilation flow, sunlight, and the droplet's residence time. Additionally, it is believed that an increase in the rate of ventilation causes a reduction in the cross infection of airborne transferred diseases through the removal or dilution of pathogen-laden airborne droplet nuclei. A higher rate of ventilation leads to the dilution of the contaminated air within the space more quickly and causes a decrease in the cross infection risk.

\section{FINDINGS}

The main results are provided in Table 1 . Of all identified studies, 10 were experimental research on HVAC systems and COVID spread (Chen and Zhao, 2020; Chirico et al., 2020; Coccia, 2020; Correia et al., 2020b; Guo et al., 2020; Haque and Rahman, 2020; Mousavi and Grosskopf, 2015; Qian and Zheng, 2018; Rosario et al., 2020; Shajahan et al., 2019). These articles were from China (2), the USA (1), Japan (1), Italy (2), Bangladesh (1), Portugal (1), Indonesia (1), and Brazil (1). Of the 20 articles, $50 \%$ (10), 30\% (6), and 20\% (4) were based on the experimental, observational, and simulation methods, respectively (Figure 1). In the next section, we discuss the most important findings. Thirteen studies concerned COVID-

Table 1. Most important specifications of reviewed articles

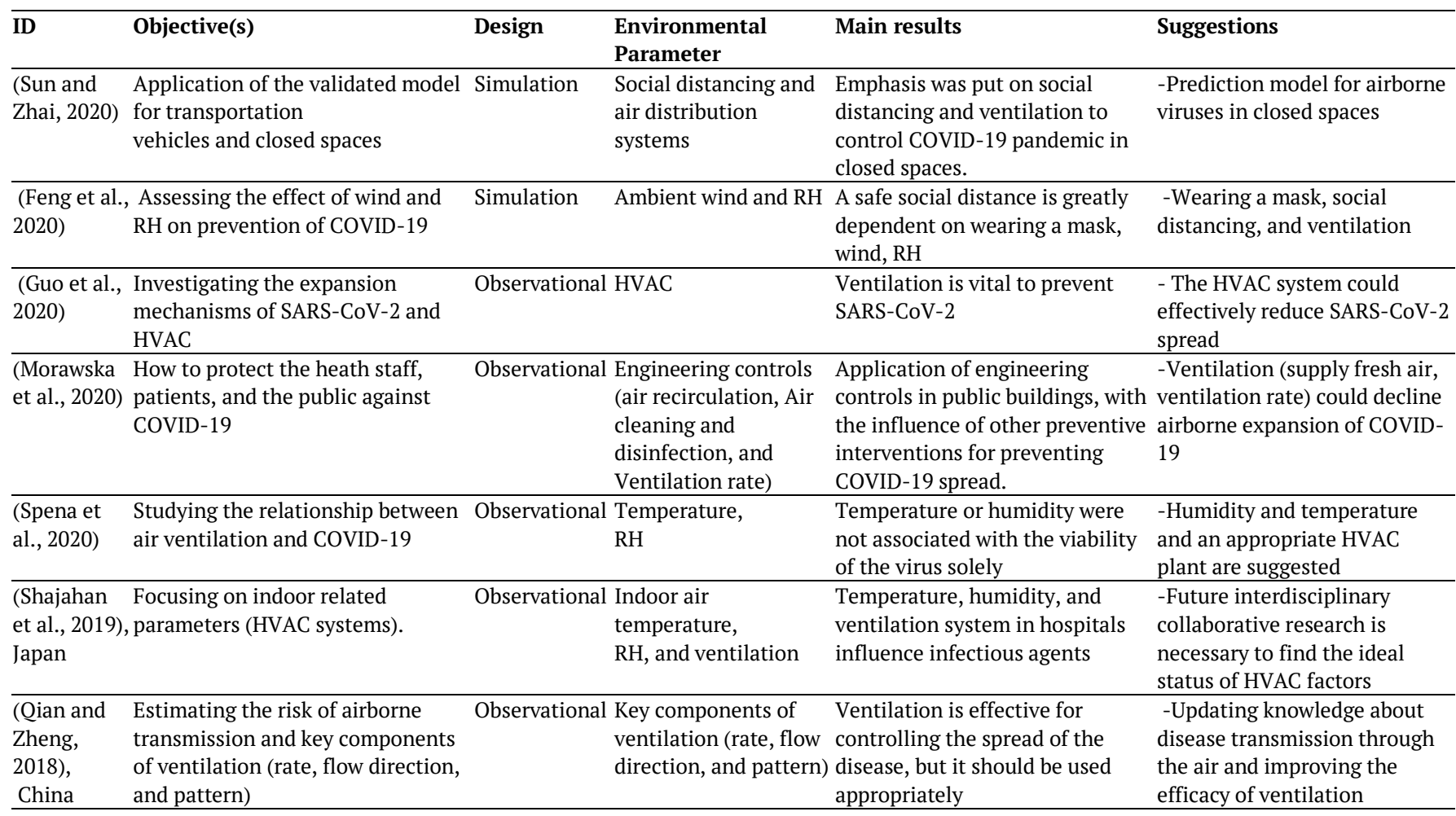


Table 1 (continued). Most important specifications of reviewed articles

\begin{tabular}{|c|c|c|c|}
\hline ID & Objective(s) & Design & $\begin{array}{l}\text { Environmental } \\
\text { Parameter }\end{array}$ \\
\hline $\begin{array}{l}\text { (Mousavi } \\
\text { and } \\
\text { Grosskopf, } \\
\text { 2015), USA }\end{array}$ & Pathogen removal using ACH & Experimental & $\begin{array}{l}\text { The relationship among } \\
\text { pathogenic origin } \\
\text { (patient) and control } \\
\text { (exhaust) }\end{array}$ \\
\hline $\begin{array}{l}\text { (Azuma et } \\
\text { al., 2020) }\end{array}$ & $\begin{array}{l}\text { Assessing the environmental } \\
\text { factors related to COVID-19 spread }\end{array}$ & Obs & $\begin{array}{l}\text { Environmental } \\
\text { factors in buildings }\end{array}$ \\
\hline
\end{tabular}

Main results Suggestions

Increased ventilation not -Negative pressurization only is not associated with recommended by healthcare more effective pathogen ventilation standards removal but also may cause negative consequences Most COVID-19 cases have -Ventilation is of crucial been infected because of close contact in closed environments, particularly inside a building

(Sarkodie Investigating the effect of climate Experimental Temperature, wind and Owusu, factors (e.g., temperature, wind 2020) speed, so on) COVID-19 spread speed, $\mathrm{RH}$ low temperature and $\mathrm{RH}$ increase the survival and spread of COVID-19 systems are not sufficient. and opening windows are of crucial importance

-Effect of variables such as health status and preventive importance to mitigate COVID-

19 spread. Usual conditioning

Hence, mechanical ventilation interventions (inter alia, socialdistancing, circulation of personal, protective equipment, and restrictive testing) must be evaluated in various countries

\begin{tabular}{llrl}
\hline $\begin{array}{l}\text { (Coccia, } \\
\text { 2020), Italy }\end{array}$ & $\begin{array}{l}\text { Studying the association between } \\
\text { wind speed, air pollution, and } \\
\text { COVID-19 expansion }\end{array}$ & $\begin{array}{r}\text { Experimental } \\
\text { Atmospheric stability, } \\
\text { air pollution, and the } \\
\text { pandemic of COVID-19 }\end{array}$ & $\begin{array}{l}\text { Geo-environmental } \\
\text { parameters may increase the } \\
\text { expansion of COVID-19 }\end{array}$ \\
$\begin{array}{l}\text { (Haque and Investigating the relation among } \\
\text { Rahman, } \\
\text { temperature, humidity, and }\end{array}$ & $\begin{array}{l}\text { Observational Temperature, RH } \\
\text { CO20), } \\
\text { Bangladesh }\end{array}$ & $\begin{array}{l}\text { Linear regression is used. } \\
\text { The results indicated that } \\
\text { high temperature and RH } \\
\text { were correlated with the } \\
\text { declined spread of COVID-19 }\end{array}$ \\
\hline (Chirico et & Evaluating the relationship & Observational Heating, ventilation, and Sufficient evidence are not
\end{tabular}

Italy ventilation systems
-A broad plan should be designed

o prevent similar future epidemics

-High temperature and RH reduce COVID-19 spread Air Conditioning available

-Hence, safety consultant should take caution furthermore, more al, 2020), between SARS-CoV-2 spread and research is needed to assess the effect of ventilation, and the risk of COVID-19 transmission

-Further studies are needed to investigate the impact of virusladen droplets and aerosols in various conditions, particularly indoor spaces

(Jayaweera Investigating the spread of COVID- Observational Droplets and aerosols et al., 2020) 19 airborne in various environmental settings have an important role in COVID-19 transmission

(Correia et Evaluating the transmission route Experimental Ventilation and aerosol HVAC is an important tool to -Using personal protective al., 2020b), of COVID-19 prevent infection equipment as well as structura changes to hospital and other facilities with HVAC systems.

Portugal

\begin{tabular}{|c|c|c|c|c|c|}
\hline $\begin{array}{l}\text { (Tosepu et } \\
\text { al., 2020), } \\
\text { Indonesia } \\
\end{array}$ & $\begin{array}{l}\text { Studying the association between } \\
\text { weather and SARS-CoV-2 }\end{array}$ & Experimental & $\begin{array}{l}\text { The least and the } \\
\text { highest temperature, } \\
\text { RH, and precipitation }\end{array}$ & $\begin{array}{l}\text { No considerable association } \\
\text { with COVID-19 }\end{array}$ & $\begin{array}{l}\text {-Climate factors are important in } \\
\text { mitigating COVID-19 }\end{array}$ \\
\hline $\begin{array}{l}\text { (Chen and } \\
\text { Zhao, } \\
\text { 2020), } \\
\text { China }\end{array}$ & $\begin{array}{l}\text { Assessing the effectiveness of } \\
\text { ventilation }\end{array}$ & Obse & $\begin{array}{l}\text { Inappropriate } \\
\text { ventilation } \\
\text { (approximately } 150 \mathrm{~m}^{3} \\
\text { per hour per person) }\end{array}$ & $\begin{array}{l}\text { High infective in makeshift } \\
\text { hospitals in Hubei Province, } \\
\text { China }\end{array}$ & $\begin{array}{l}\text { ventilation is of crucial } \\
\text { ce }\end{array}$ \\
\hline $\begin{array}{l}\text { (Rosario et } \\
\text { al., 2020), } \\
\text { Brazil }\end{array}$ & $\begin{array}{l}\text { Studying the association between } \\
\text { SARS-CoV- } 2 \text { and climate }\end{array}$ & Exp & $\begin{array}{l}\text { Temperature, } \mathrm{RH} \text {, and } \\
\text { UV-B radiation }\end{array}$ & $\begin{array}{l}\text { Increased spread of SARS- } \\
\text { CoV-2 }\end{array}$ & $\begin{array}{l}\text {-Climate factors are important } \\
\text { for preventing COVID-19 spread }\end{array}$ \\
\hline $\begin{array}{l}\text { (Karapiperis } \\
\text { et al., 2020) }\end{array}$ & $\begin{array}{l}\text { Investigating the ultraviolet } \\
\text { radiation relationship with Covid- } \\
19\end{array}$ & Obs & $\begin{array}{l}\text { Sunlight and UV } \\
\text { radiation }\end{array}$ & $\begin{array}{l}\text { Decay the viability of } \\
\text { COVID-19 }\end{array}$ & $\begin{array}{l}\text {-There is an association between } \\
\text { UV and SARS-CoV-2 spread in } \\
\text { altitudes and not latitudes }\end{array}$ \\
\hline $\begin{array}{l}\text { (Bhagat et } \\
\text { al., 2020) }\end{array}$ & $\begin{array}{l}\text { Studying the effect of building } \\
\text { ventilation on the possible } \\
\text { pathways of airborne particles and } \\
\text { examining the fluid mechanics }\end{array}$ & Sim & $\begin{array}{l}\text { ventilation } \\
\text { states and amount of } \\
\text { bio-aerosol }\end{array}$ & $\begin{array}{l}\text { Flows related to dispersion } \\
\text { of aerosols indoors }\end{array}$ & $\begin{array}{l}\text {-It is of importance to } \\
\text { understand airflows for } \\
\text { estimation of the risk of } \\
\text { contracting COVID-19 }\end{array}$ \\
\hline
\end{tabular}

19 and four concerned SARS-CoV-2. According to this study, about $70 \%$ of reported research studies were associated with indoor settings (hospital, health care center, and restaurant) and about $30 \%$ of research studies with outdoor environment.

\section{DISCUSSION}

In this research, a comprehensive literature review was conducted concerning the relationship between HVAC systems and SARS-CoV-2 spread. In total 20 articles were found to be eligible for a full evaluation. Ten articles were observational and had investigated the association between 


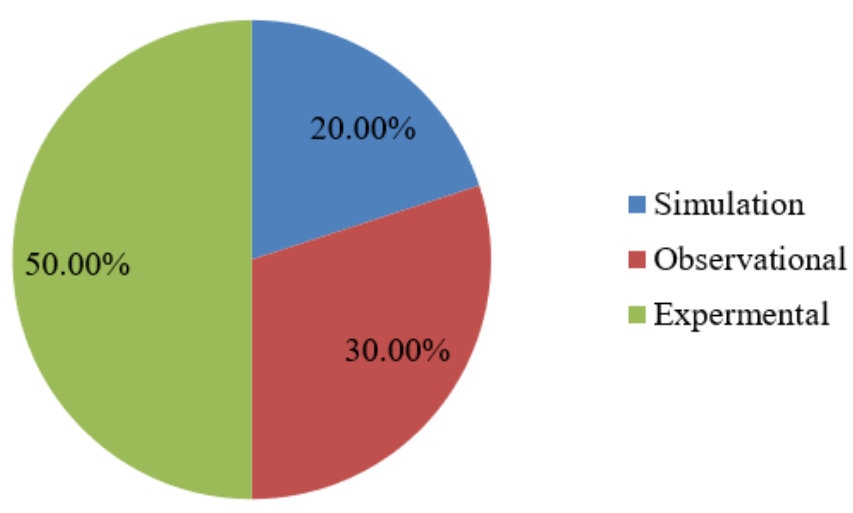

Figure 1. Specification type of design articles

HVAC systems (i.e., effectiveness and key elements) and COVID-19 spread.

Eight of the 20 included studies on poor ventilation, effective ventilation, and key elements of ventilation to prevent COVID-19. There are many studies about temperature and humidity, reporting that humidity should range from 40 to $60 \%$ and temperature should be $21-23^{\circ} \mathrm{C}$ (Guo et al., 2020). However, low RH (<20\%) is known to increase an individual's susceptibility to infection (Dietz et al., 2019). Another study suggested that, in hospitals, RH should be $30 \%$ to $60 \%$ (Balaras et al., 2007). In a study, coronavirus was reported to survive longer in conditions with lower $\mathrm{RH}(<50 \%)$ and to be eliminated at $\mathrm{RH}>80 \%$ due to having a lipid envelope (Correia et al., 2020a). Additionally, it was found that as time passes, the low humidity in combination with high temperature might result in an infectious dose (Somsen et al., 2020b). Overall, results of the studies showed that the optimal humidity is associated with temperature, space, and type of microorganisms.

Considering the hospital buildings, various studies suggested separate thermal zones to meet the needs of patients: Operating room $24-26^{\circ} \mathrm{C}\left(74.2-78.8^{\circ} \mathrm{F}\right)$, labor room $\geqslant 26^{\circ} \mathrm{C}\left(78.8^{\circ} \mathrm{F}\right)$, infants department (around $28^{\circ} \mathrm{C}\left(82.4^{\circ} \mathrm{F}\right)$ ), patients' room $\left(21-24^{\circ} \mathrm{C}\left(70-75^{\circ} \mathrm{F}\right)\right)$, and bronchoscopy (20$\left.23^{\circ} \mathrm{C}\left(68-73^{\circ} \mathrm{F}\right)\right)($ Knobel and Holditch-Davis, 2007; Lyon and Freer, 2011). Initially COVID-19 pandemic was more severe in countries with lower temperatures (Hassan et al., 2020). One study reported a considerable negative association between temperature and COVID-19 attack rate (Hassan et al., 2020). Another research reported a negative association between temperature and RH and COVID-19 mortality (Ma et al., 2020). However, there are studies that reported no association between COVID-19 spread and temperature (Xie and Zhu, 2020; Yao et al. 2020). Another research found a positive association between COVID-19 cases and a threshold of $3^{\circ} \mathrm{C}$ (Xie and Zhu, 2020). The results from one study indicated that there is not strong evidence suggesting the spread of SARS$\mathrm{CoV}-2$ via aerosol transfer through HVAC systems (Belingheri et al., 2020). Moreover, modeling research on the viral particles scattering for COVID-19, which in the first SARS pandemic strongly confirmed the likelihood of SARS-CoV-1 aerosols capturing and re-diffusing by HVAC, is not yet available (Chirico et al., 2020). Three of the twenty included studies examined two factors basic strategy of control COVID19 include: effective ventilation, and social distancing, Sun and Zhai reported that social distancing and ventilation effectiveness had a great positive impact on decreasing the infection risk COVID-19 (Sun and Zhai, 2020). Of the 20 studies, three investigated two basic strategies to control COVID-19, including effective ventilation, and social distancing (Sun and Zhai, 2020). One study conducted on the effect of hydrological parameters (river length, lake area, rain, and water resources) on the SARS-CoV-2 pandemic reported that hydrological parameters play an important role in SARSCoV-2 spread (Wang et al., 2020). Jayaweera et al. reported that ventilation may cause transmission of the virus to taxi passengers (Jayaweera et al., 2020). Nine of the 20 included studies investigating the influence of environmental factors, such as ultraviolet radiation, wind speed, surface pressure, temperature, and $\mathrm{RH}$ on prevention of SARS-CoV-2 (Feng et al., 2020; Haque and Rahman, 2020; Karapiperis et al., 2020; Rosario et al., 2020; Sarkodie and Owusu, 2020; Spena et al., 2020; Tosepu et al., 2020; Xie and Zhu, 2020; Yao et al., 2020). They reported a negative correlation between temperature and RH and COVID-19 spread. Poole found a positive correlation between temperature and climate latitude and COVID-19 (Poole, 2020). Three of the 20 included articles reported an association between air conditioning and COVID-19 transmission (Coccia, 2020; Correia et al., 2020b; Tosepu et al., 2020). These studies reported that low wind speed declines the expansion of gaseous and particulate matters, which in turn reduces the COVID-19 spread. Results from this study revealed the crucial role of ventilation systems in preventing the infection. Ventilation is a primary strategy used in hospitals and other facilities to control infectious diseases (Correia et al., 2020a). According to Chirico et al., ventilation may lead to the infection spread (Chirico et al., 2020). Ventilation systems are capable of acting as a route to transfer infectious diseases such as SARS, measles, tuberculosis, chickenpox, influenza, rhinovirus, and smallpox (Shiu et al., 2019). As the most important climate factor, solar radiation was significantly correlated with the COVID-19 prevalence (Rosario et al., 2020). According to Dabisch et al., temperature, simulated sunlight, and humidity are among significant factors affecting the infectious SARS-CoV-2 durability in aerosols (Dabisch et al., 2020). Additionally, in enclosed spaces, low humidity, air conditioning, and low UV light may cause viral aerosol to survive longer (Bulfone et al., 2020). Results from this study indicated that the main transmission route for COVID-19 was person to person contact (Zhang et al., 2020).

However, the results reported by the mentioned studies are inconsistent, and conducting a comparative study is thus difficult. To decline exposure to SARS-CoV-2, the following interventions are suggested to improve indoor air environments and prevent COVID-19 infection:

1- Using healthcare facilities to reduce COVID-19 spread, including environmental engineering controls like e.g., negative pressure rooms, dilution ventilation, highefficiency particulate air filtration, ultraviolet germicidal irradiation (UVGI), and scavenging equipment;

2- Applying a broad plan to prevent similar future epidemics by an emphasis on climate factors;

3- Considering traditional infection control hierarchy, including elimination (to physically remove the 
pathogen), engineering controls (to separate people and pathogen), administrative controls (to instruct people what to do), and personal protective equipment (to use masks, gowns, gloves, and other smart PPE), respectively (Gordon et al., 2020).

4- Applying countermeasures using HVAC systems, including interventions related to air-cleaning and controlling temperature and humidity.

5- Applying key strategies to improve indoor air quality (IAQ) against airborne infection, including adequate ventilation and temperature control.

6- Conducting further studies to find the optimum ranges for indoor-related conditions, particularly in health care settings.

7- Mitigating the virulence of SARS-CoV-2 for closed spaces by air changes and HVAC systems.

8- Researchers, decision-makers, policymakers, and architects should perceive the importance of indoor environmental factors. Besides, special standards should be designed for HVAC systems.

9- A brief report on the impact of climate factors and COVID-19 spread would be useful.

\section{CONCLUSIONS}

There are different points of view about the influence of the ventilation systems on preventing SARS-CoV-2 spread. Evidence is not sufficient to make a definitive conclusion regarding the correlation between ventilation systems and SARS-CoV-2 spread. The national and international agencies publish guidelines for prevention of SARS-CoV-2 transmission in closed spaces based on the conducted research studies. In the present study, 20 articles were fully reviewed. The research studies' main variables, parameters (e.g., ambient wind, air recirculation, rate of ventilation, aerosols, $\mathrm{RH}$, and temperature), and results were gathered. This review revealed the significant role of ventilation in mitigating COVID-19 spread in indoor air environments. The obtained results also indicated that enhancing the ventilation effectiveness may play a key role in limiting the SARS-CoV-2 virus transmission. Accordingly, some interventions should be designed to prevent disease expansion, such as separating people and pathogen, instructing people what to do, using personal protective equipment, providing better ventilation in health care settings, particularly in hospitals and populated areas, observing social distancing, setting the minimum standard of heating, ventilation, air conditioning (HVAC) systems, etc. Finally, six factors of the basic strategy to control COVID-19 include: hand hygiene, social distancing, screening and case finding, isolation and separating, decontamination and disinfection, and effective ventilation.

Funding: The author declares no funding sources or grants were attributed to this work.

Declaration of interest: The author declares no competing interests.

Ethics approval and consent to participate: Not applicable.
Availability of data and materials: All data generated or analyzed during this study are available for sharing when appropriate request is directed to the author.

\section{REFERENCES}

Anfinrud, P., Bax, C. E., Stadnytskyi, V. and Bax, A. (2020). Could SARS-CoV-2 be transmitted via speech droplets? medRxiv. https://doi.org/10.1101/2020.04.02.20051177

Azuma, K., Yanagi, U., Kagi, N., Kim, H., Ogata, M. and Hayashi, M. (2020). Environmental factors involved in SARS-CoV-2 transmission: effect and role of indoor environmental quality in the strategy for COVID-19 infection control. Environmental health and preventive medicine, 25(1), 1-16. https://doi.org/10.1186/s13568-02001028-0

Balaras, C. A., Gaglia, A. G., Georgopoulou, E., Mirasgedis, S., Sarafidis, Y. and Lalas, D. P. (2007). European residential buildings and empirical assessment of the Hellenic building stock, energy consumption, emissions and potential energy savings. Building and environment, 42(3), 1298-1314. https://doi.org/10.1016/j.buildenv.2005.11.001

Belingheri, M., Paladino, M. E. and Riva, M. A. (2020). COVID19: health prevention and control in non-healthcare settings. Oxford University Press UK. https://doi.org/10.1093/ occmed/kqaa048

Bhagat, R. K., Wykes, M. D., Dalziel, S. B. and Linden, P. (2020). Effects of ventilation on the indoor spread of COVID-19. Journal of Fluid Mechanics, 903, F1. https://doi.org/ 10.1017/jfm.2020.720

Bourouiba, L. (2020). Turbulent gas clouds and respiratory pathogen emissions: potential implications for reducing transmission of COVID-19. Jama, 323(18), 1837-1838. http://doi:10.1001/jama.2020.4756

Bulfone, T. C., Malekinejad, M., Rutherford, G. W. and Razani, N. (2020). Outdoor Transmission of SARS-CoV-2 and Other Respiratory Viruses, a Systematic Review. The Journal of infectious diseases, 223(4), 550-561. https://doi.org/10.1093 /infdis/jiaa742

Chen, C. and Zhao, B. (2020). Makeshift hospitals for COVID19 patients: where health-care workers and patients need sufficient ventilation for more protection. Journal of Hospital Infection, 105(1), 98-99. https://doi.org/10.1016/ j.jhin.2020.03.008

Chirico, F., Sacco, A., Bragazzi, N. L. and Magnavita, N. (2020). Can air-conditioning systems contribute to the spread of SARS/MERS/COVID-19 infection? Insights from a rapid review of the literature. International Journal of Environmental Research and Public Health, 17(17), 6052. https://doi.org/10.3390/ijerph17176052

Coccia, M. (2020). The effects of atmospheric stability with low wind speed and of air pollution on the accelerated transmission dynamics of COVID-19. International Journal of Environmental Studies, 78(1), 1-27. https://doi.org/ 10.1080/00207233.2020.1802937 
Correia, G., Rodrigues, L., Da Silva, M. G. and Gonçalves, T. (2020). Airborne route and bad use of ventilation systems as non-negligible factors in SARS-CoV-2 transmission. Medical Hypotheses, 141, 109781. https://doi.org/ 10.1016/j.mehy.2020.109781

Dabisch, P., Schuit, M., Herzog, A., Beck, K., et al. (2020). The influence of temperature, humidity, and simulated sunlight on the infectivity of SARS-CoV-2 in aerosols. Aerosol Science and Technology, 55(2), 142-153. https://doi.org/10.1080/02786826.2020.1829536

Dietz, L., Horve, P., Coil, D., Fretz, M., Eisen, J. and Van Den Wymelenberg, K. (2019). novel coronavirus (COVID-19) pandemic: built environment considerations to reduce transmission. mSystems, 5(2), e00245-20. https://doi.org/ 10.1128/mSystems.00245-20

Feng, Y., Marchal, T., Sperry, T. and Yi, H. (2020). Influence of wind and relative humidity on the social distancing effectiveness to prevent COVID-19 airborne transmission: A numerical study. Journal of Aerosol Science, 147, 105585. https://doi.org/10.1016/j.jaerosci.2020.105585

Gordon, D., Ward, J., Yao, C. J. and Lee, J. (2020). Built Environment Airborne Infection Control Strategies in Pandemic Alternative Care Sites. HERD: Health Environments Research \& Design Journal, 1937586720979832.

https://doi.org/10.1177/1937586720979832

Guo, M., Xu, P., Xiao, T., He, R., Dai, M. and Zhang, Y. (2020). Review and comparison of HVAC operation guidelines in different countries during the COVID-19 pandemic. Building and Environment, 187, 107368. https://doi.org/10.1016/j.buildenv.2020.107368

Haque, S. E. and Rahman, M. (2020). Association between temperature, humidity, and COVID-19 outbreaks in Bangladesh. Environmental science \& policy, 114, 253-255. https://doi.org/10.1016/j.envsci.2020.08.012

Hassan, M. M., El Zowalaty, M. E., Khan, S. A., Islam, A., Nayem, M. R. K. and Järhult, J. D. (2020). Role of Environmental Temperature on the Attack rate and Case fatality rate of Coronavirus Disease 2019 (COVID-19) Pandemic. Infection ecology \& epidemiology, 10(1), 1792620. https://doi.org/10.1080/20008686.2020.1792620

Jayaweera, M., Perera, H., Gunawardana, B. and Manatunge, J. (2020). Transmission of COVID-19 virus by droplets and aerosols: A critical review on the unresolved dichotomy. Environmental Research, 188, 109819. https://doi.org/ 10.1016/j.envres.2020.109819

Karapiperis, C., Kouklis, P., Papastratos, S., Chasapi, A. and Ouzounis, C. (2020, April 1). Assessment for the seasonality of Covid-19 should focus on ultraviolet radiation and not 'warmer days'. https://doi.org/10.31219/osf.io/397yg

Knobel, R. and Holditch-Davis, D. (2007). Thermoregulation and heat loss prevention after birth and during neonatal intensive-care unit stabilization of extremely lowbirthweight infants. Journal of Obstetric, Gynecologic \& Neonatal Nursing 36(3), 280-287. https://doi.org/10.1111/ j.1552-6909.2007.00149.x
Kramer, A., Schwebke, I. and Kampf, G. (2006). How long do nosocomial pathogens persist on inanimate surfaces? A systematic review. BMC Infectious Diseases, 6(1), 130. https://doi.org/10.1186/1471-2334-6-130

Lu, J., Gu, J., Li, K., Xu, C., et al. (2020). COVID-19 outbreak associated with air conditioning in restaurant, Guangzhou, China, 2020. Emerging Infectious Diseases, 26(7), 1628. https://doi.org/10.3201/eid2607.200764

Lyon, A. and Freer, Y. (2011). Goals and options in keeping preterm babies warm. Archives of Disease in Childhood-Fetal and Neonatal Edition, 96(1), F71-F74. https://doi.org/ 10.1136/adc.2009.161158

Ma, Y., et al. (2020). Effects of temperature variation and humidity on the death of COVID-19 in Wuhan, China. Science of The Total Environment, 724, 138226. https://doi.org/10.1016/j.scitotenv.2020.138226

Morawska, L., et al. (2020). How can airborne transmission of COVID-19 indoors be minimised? Environment International, 142, 105832 https://doi.org/10.1016/ j.envint.2020.105832

Mousavi, E. S. and Grosskopf, K. R. (2015). Ventilation rates and airflow pathways in patient rooms: A case study of bioaerosol containment and removal. Annals of Occupational Hygiene, 59(9), 1190-1199. https://doi.org/ 10.1093/annhyg/mev048

Mousavi, E. S., Kananizadeh, N., Martinello, R. A. and Sherman, J. D. (2020). COVID-19 Outbreak and hospital air quality: A systematic review of evidence on air filtration and recirculation. Environmental Science \& Technology. https://doi.org/10.1021/acs.est.0c03247

Poole, L. (2020). Seasonal Influences on the Spread of SARSCoV-2 (COVID19), Causality, and Forecastability. https://doi.org/10.2139/ssrn.3554746

Qian, H. and Zheng, X. (2018). Ventilation control for airborne transmission of human exhaled bio-aerosols in buildings. Journal of Thoracic Disease, 10(Suppl 19), S2295.

Rosario, D. K., Mutz, Y. S., Bernardes, P. C. and Conte-Junior, C. A. (2020). Relationship between COVID-19 and weather: Case study in a tropical country. International Journal of Hygiene and Environmental Health, 229, 113587.

Sarkodie, S. A. and Owusu, P. A. (2020). Impact of meteorological factors on COVID-19 pandemic: Evidence from top 20 countries with confirmed cases. Environmental Research, 191, 110101. https://doi.org/10.1016/j.envres. 2020.110101

Shajahan, A., Culp, C. H. and Williamson, B. (2019). Effects of indoor environmental parameters related to building heating, ventilation, and air conditioning systems on patients' medical outcomes: A review of scientific research on hospital buildings. Indoor Air, 29(2), 161-176. https://doi.org/10.1111/ina.12531

Shiu, E. Y., Leung, N. H. and Cowling, B. J. (2019). Controversy around airborne versus droplet transmission of respiratory viruses: implication for infection prevention. Current Opinion in Infectious Diseases, 32(4), 372-379. https://doi.org/10.1097/QCO.0000000000000563 
Sjödin, H., Wilder-Smith, A., Osman, S., Farooq, Z. and Rocklöv, J. (2020). Only strict quarantine measures can curb the coronavirus disease (COVID-19) outbreak in Italy, 2020. Eurosurveillance, 25(13), 2000280. https://doi.org/ 10.2807/1560-7917.ES.2020.25.13.2000280

Somsen, G. A., van Rijn, C., Kooij, S., Bem, R. A. and Bonn, D. (2020). Small droplet aerosols in poorly ventilated spaces and SARS-CoV-2 transmission. The Lancet Respiratory Medicine, 8(7), 658-659. https://doi.org/10.1016/S22132600(20)30245-9

Spena, A., Palombi, L., Corcione, M., Carestia, M. and Spena, V. A. (2020). On the optimal indoor air conditions for SARS-CoV-2 inactivation. An enthalpy-based approach. International Journal of Environmental Research and Public Health, 17(17), 6083. https://doi.org/10.3390/ijerph1717 6083

Sun, C. and Zhai, Z. (2020). The efficacy of social distance and ventilation effectiveness in preventing COVID-19 transmission. Sustainable Cities and Society, 62, 102390. https://doi.org/10.1016/j.scs.2020.102390

Tang, J. W. (2009). The effect of environmental parameters on the survival of airborne infectious agents. Journal of the Royal Society Interface, 6(suppl_6), S737-S746. https://doi.org/10.1098/rsif.2009.0227.focus

Tosepu, R., Gunawan, J., Effendy, D. S., Lestari, H., Bahar, H. and Asfian, P. (2020). Correlation between weather and Covid-19 pandemic in Jakarta, Indonesia. Science of The Total Environment, 725, 138436. https://doi.org/10.1016/ j.scitotenv.2020.138436
Wang, J., Li, W., Yang, B., Cheng, X., Tian, Z. and Guo, H. (2020). Impact of hydrological factors on the dynamic of COVID-19 epidemic: A multi-region study in China. Environmental Research, 110474. https://doi.org/10.1016/ j.envres.2020.110474

Xie, J. and Zhu, Y. (2020). Association between ambient temperature and COVID-19 infection in 122 cities from China. Science of the Total Environment, 724, 138201. https://doi.org/10.1016/j.scitotenv.2020.138201

Yao, Y., et al. (2020) No Association of COVID-19 transmission with temperature or UV radiation in Chinese cities. European Respiratory Journal 55(5), 2000517. https://doi.org/10.1183/13993003.00517-2020

Zhang, S., Diao, M., Yu, W., Pei, L., Lin, Z. and Chen, D. (2020). Estimation of the reproductive number of novel coronavirus (COVID-19) and the probable outbreak size on the Diamond Princess cruise ship: A data-driven analysis. International Journal of Infectious Diseases, 93, 201-204. https://doi.org/10.1016/j.ijid.2020.02.033

Zhu, S., Jenkins, S., Addo, K., Heidarinejad, M., et al. (2020). Ventilation and laboratory confirmed acute respiratory infection (ARI) rates in college residence halls in College Park, Maryland. Environment International, 137, 105537. https://doi.org/10.1016/j.envint.2020.105537 